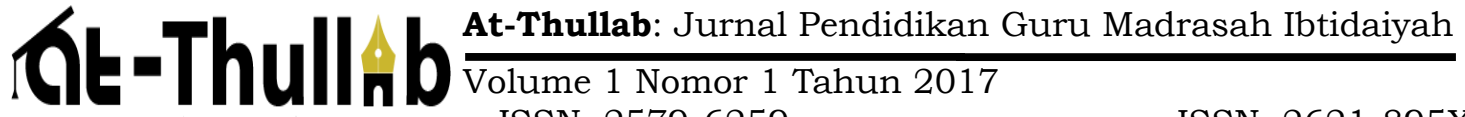 \\ Jurnal Peandididkan Guru Madrasash lbtidalizah p-ISSN: 2579-6259 \\ e-ISSN: 2621-895X
}

\section{MODEL PEMBELAJARAN AKIDAH AKHLAK MELALUI RELIGIOUS CULTURE DI MIN BLORA DAN MI TARIS PATI}

\author{
Elya Umi Hanik \\ Program Studi Pendidikan Guru Madrasah Ibtidaiyah \\ Universitas Islam Lamongan \\ e-mail : elyaumi@yahoo.com
}

\begin{abstract}
Abstrack: The one of problem for student is dcreasing moral, in this case, study akidah akhlak seeks to establish personal morals learners in terms akidah and akhlak. Learning akidah akhlak not only focused on cognitive aspects but also the establishment of affective and psychomotor through religious culture that will ultimately achieve the goal of learning is the formation of the character of the students. This study aims to 1) analyze the application of akidah akhlak learning through religious culture in Islamic Elementary School (MIN) Plosorejo, Blora and Islamic Elementary School Tarbiyatul Islamiyah Winong, Pati. 2) analyze the effects of Akidah Akhlak learning to form the students' characters through religious culture in Islamic Elementary School (MIN) Plosorejo, Blora and Islamic Elementary School Tarbiyatul Islamiyah Winong, Pati. This research is multi-case qualitative in Islamic Elementary School (MIN) Plosorejo, Blora. And 2) Islamic Elementary School Tarbiyatul Islamiyah Winong, Pati. Data collection was done through deep interviews, documentations, and observations. Some steps used to have data validity involved zealous observation, triangulations, and enough references. The analysis was done by following the data collection steps, data reduction, data presentation, and verification. The results of the study included 1)The learning process of Akidah Akhlak was done contextually in the form of well learning whether inside or outside of the class through various learning methods involved modeling, discipline, habit, punishment and reward, and motivation. In the implementation of religious values, these hierarchies of steps were done as follows: creating religious value, speeches and advises, models, habit, extracurricular activity, posters with Hadist or motivating words which were attached to the wall, forming the leader's soul through religious activity. 2) The effects of Akidah Akhlak learning through religious culture in Islamic Elementary School Plosorejo, Blora and Islamic Elementary School Tarbiyatul Islamiyah Winong, Pati were able to form the students' characters in the expectation of religious values, independent, communicative, discipline, caring about surrounding, responsible, social care, and willing to know, and secondly to form the students' achievement in every side of academic.
\end{abstract}

Kaywords: Moral Learning, Students Character, Religious Culture 


\section{A. Pendahuluan}

Pendidikan memegang peranan yang amat penting untuk menjamin kelangsungan hidup suatu masyarakat atau bangsa. Hal ini disebabkan pendidikan merupakan wahana untuk meningkatkan dan mengembangkan kualitas sumber daya manusia. Sebagaimana telah dirumuskan dalam UU Sisdiknas No 20 Tahun 2003 tentang Sistem Pendidikan Nasional bahwa Pendidikan Nasional berfungsi mengembangkan kemampuan dan membentuk watak serta peradaban bangsa yang bermartabat dalam rangka mencerdaskan kehidupan bangsa, bertujuan untuk berkembangnya potensi peserta didik agar menjadi manusia yang beriman dan bertakwa kepada Tuhan Yang Maha Esa, berakhlak mulia, sehat, berilmu, cakap, kreatif, mandiri, dan menjadi warga negara yang demokratis serta bertanggung jawab (Nasional, 2003). Demikian jika kita cermati, sudah jelas bahwasanya titik poin tujuan akhir dari pendidikan adalah membentuk peserta didik yang berilmu yang didasari keimanan dan ketakwaan kepada Tuhan Yang Maha Esa, bermoral dan memiliki akhlak yang baik. Akan tetapi idealitas yang dicita- citakan tidak sejalan dengan realitas yang terjadi. Salah satu masalah bagi peserta didik adalah dekandensi moral yang kini telah dirasakan mengglobal seiring dengan perubahan tata nilai yang sifatnya mendunia (Muhaimin, 2005). Kemerosotan moral nampaknya menjadi masalah yang sangat urgen untuk segera dibenahi. Hal tersebut dapat kita lihat dari berbagai penyimpanganpenyimpangan sosial di sekitar kita.

Melihat fenomena dan kausalitas tersebut, tentunya dapat menjadi suatu refleksi, bahwasanya memang perlu adanya usaha membentuk peserta didik sesuai tujuan pendidikan. Oleh karenanya untuk membentuk kepribadian peserta didik sesuai dengan tujuan yang diharapkan perlu adanya bimbingan dan pembinaan peserta didik menjadi manusia yang beriman dan bertakwa kepada Tuhan Yang Maha Esa serta berakhlak mulia. Berkenaan dengan hal ini, untuk membentuk dan mengarahkan peserta didik sesuai dengan tujuan pendidikan dalam hal ini, pendidikan agama Islam memiliki tiga komponen utama sebagai dasar pembelajarannya, yang meliputi akidah yang unsur materinya berisi tauhid dan iman, ibadah yang materinya berisi tata cara pelaksanaan ibadah ritual dan akhlak yang menekankan pada tata cara hubungan antara manusia dengan manusia lain, hubungan dengan Tuhan dan hubungan dengan alam (RI, 2011). Berangkat dari sinilah seharusnya upaya menanamkan iman itu menjadi hal yang prioritas diterapkan pada peserta didik. Sedangkan pada aspek akhlak, yakni sebagai manifestasi dan konsekuensi dari keimanan dan keyakinan hidup.Akhlak merupakan aspek sikap hidup atau kepribadian hidup manusia, yang mengatur hubungan manusia dengan Allah SWT dan hubungan manusia dengan manusia lainnya. Hal itu menjadi sikap hidup dan kepribadian hidup manusia dalam menjalankan sistem kehidupannya (politik, ekonomi, sosial, pendidikan, kekeluargaan, kebudayaan/seni, ilmu pengetahuan 
dan teknologi olahraga/kesehatan, dan lain-lain) yang dilandasi oleh akidah yang kokoh (Permenag, 2008).

Berdasarkan konsep pendidikan akidah akhlak tersebut, maka sangatlah perlu dibelajarkan kepada peserta didik, sebagai jembatan mewujudkan peserta didik yang berilmu dengan dasar keimanan dan berakhlak. Oleh karenanya sejak pendidikan dasar seyogyanya ditanamkan. Adapun dalam proses pembelajaran akidah akhlak itu menurut Amin Abdullah dalam Mulkan yang dikutip Muhaimin, bahwa terdapat tiga tahapan proses pendidikan agama (termasuk Akidah-Akhlak) yang seharunya dimiliki dan dialami oleh anak didik bersama-sama dengan guru yaitu dari tahapan kognisi, afeksi hingga psikomotor. Pendidikan akidah akhlak tidak sekedar terkonsentrasi pada persoalan teoritis yang bersifat kognitif semata, tetapi sekaligus juga mampu mengubah pengetahuan akidah akhlak yang bersifat kognitif menjadi makna dan nilai- nilai yang perlu diinternalisasikan dalam diri peserta didik lewat berbagai cara, media dan forum. Selanjutnya "makna" dan "nilai" yang terhayati tersebut dapat menjadi sumber motivasi bagi peserta didik untuk bergerak, berbuat, berperilaku secara konkret-agamis dalam wilayah kehidupan praksis sehari- hari (Muhaimin, 2004).

Realitas pelaksanaan pembelajaran akidah akhlak tentunya masih terdapat kelemahan-kelemahan yang mendorong dilakukannya penyempurnaan terus menerus. Dalam praktekknya akidah akhlak sebagai materi pelajaran lebih berfokus pada pengayaan, pengetahuan (kognitif) dan minim dalam pembentukan sikap (afektif) serta pembiasaan (psikomotorik). Kendala lain adalah kurangnya keikutsertaan guru mata pelajaran lain dalam memberi motivasi kepada peserta didik untuk mempraktikkan nilai-nilai keyakinan tauhid dan akhlakul karimah dalam kehidupan sehari-hari. Lemahnya sumber daya guru dalam mengembangkan model, pendekatan dan metode pembelajaran yang lebih variatif, selain itu tantangan yang dihadapi dalam pendidikan agama Islam khususnya pada pendidikan akidah akhlak sebagai sebuah mata pelajaran adalah bagaimana mengimplementasikan pendidikan akhlak bukan hanya mengajarkan pada tataran kognisi yaitu mengajarkan pengetahuan tentang akidah akhlak dan akhlak akan tetapi bagaimana mengarahkan dan mengimplementasikan pendidikan akidah akhlak, agar mempunyai akidah yang kokoh, dan akhlak yang baik, sehingga dari akidah yang kokoh dan akhlak yang baik terbentuklah peserta didik yang berkarakter berlandaskan nilai-nilai Islam. Sebagai upaya mewujudkan pembelajaran akidah akhlak yang sejalan dengan karakteristik dan tujuan pembelajaran akidah akhlak, maka perlu adanya inovasi dalam proses dan pelaksanaan pembelajaran akidah akhlak serta upaya fungsionalisasi peran akidah akhlak seoptimal mungkin melalui pembenahan kurikulum dan model pembelajaran yang berkualitas bagi pembentukan peserta didik yang berkarakter. 
Selain melalui inovasi dalam proses pembelajaran akidah akhlak, upaya lain untuk mewujudkan pembelajaran akidah akhlak yang tidak sekedar pengetahuan kognisi tetapi juga ranah afektif dan psikomotorik, tidak sekedar teori tetapi juga aplikasi aksi di lingkungan madrasah, tentunya perlu adanya internalisasi nilai-nilai agama itu sendiri pada peserta didik, yaitu melalui proses pembinaan secara berkelanjutan mulai dari proses moral knowing, moral feeling hingga moral action, dengan begitu berbagai potensi peserta didik dapat berkembang secara optimal, baik pada aspek kesehatan jasmanai, kecerdasan emosional maupun kecerdasan spi (Muhaimin, 2005). Kemerosotan moral nampaknya menjadi masalah yang sangat urgen untuk segera dibenahi. Hal tersebut dapat kita lihat dari berbagai penyimpangan- penyimpangan sosial di sekitar kita.

Berdasarkan kajian ini, peneliti ingin menganalisis dengan melihat realitas yang ada di Madrasah terkait bagaimana pembentukan karakter peserta didik melalui pembelajaran akidah akhlak dengan perwujudan budaya religius yang diciptakan oleh Madrasah. Seperti apa dan bagaiman model pembelajaran yang kemudian secara praktis diterapkan lewat budaya religius Madrasah. Dalam hal ini objek yang menjadi penilitian adalah MIN Plosorejo Blora dan MI Tarbiyatul Islamiyah Winong Pati. Kedua madrasah tersebut memiliki ciri khas dan keunggulan dalam membentuk akhlak peserta didiknya. Dengan demikian penulis memfokus tema penelitian ini pada Pembelajaran Akidah Akhlak dalam Membentuk Karakter Peserta Didik Melalui Budaya Religius di MIN Plosorejo Blora dan MI Tarbiyatul Islamiyah Winong Pati. Adapun tujuan penelitan ini 1) Mendeskripsikan dan menganalisis model pelaksanaan pembelajaran akidah akhlak melalui budaya religius di MIN Plosorejo Blora dan MI Tarbiyatul Islamiyah Winong Pati.2) Mendeskripsikan dan menganalisis dampak model pembelajaran akidah akhlak melalui budaya religius dalam membentuk karakter peserta didik di MIN Plosorejo Blora dan MI Tarbiyatul Islamiyah Winong Pati

\section{Pembelajaran Akidah Akhlak dalam Membentuk Karakter Peserta Didik Madrasah Ibtidaiyah}

1. Hakekat Pembelajaran Akidah Akhlak

Pada hakekatnya belajar adalah suatu proses yang ditandai dengan adanya perubahan pada diri seseorang. Perubahan sebagai hasil dari proses belajar, yanga dapat diindikasikan dalam berbagai bentuk seperti berubah pegetahuan, pemahaman, sikap dan tingkah laku, kecakapan, ketrampilan dan kemampuan, serta perubahan aspek-aspek yang lain yang ada pada individu yang belajar (Trianto, 2009). Dengan demikian inti belajar adalah adanya perubahan tingkah laku karena suatu pengalaman. Perubahan tingkah laku tersebut dapat berupa perubahan ketrampilan, kebiasaan, sikap, pengetahuan, pemahaman, dan apresiasi. Menurut Ahmad 
Mudzakar bahwa belajar adalah usaha atau kegiatan yang bertujuan mengadakan perubahan dalam diri seseorang mencakup perubahan tingkah laku, sikap kebiasaan,ilmu pengetahuan, ketrampilan dan sebagainya (Anas, n.d.). Dalam implementasinya, pada mata pelajaran akidah akhlak di madrasah Ibtidaiyah, maka pembelajaran akidah akhlak harusnya berjalan sesuai dengan tujuan pembelajaran mata pelajaran akidah akhlak di Madrasah Ibtidaiyah. Untuk mewujudkan pembelajaran yang nantinya dapat membentuk karakter peserta didik, terdapat beberapa unsur- unsur pembentuknya diantaranya adalah:

1) Merumuskan visi, misi dan tujuan Madrasah

2) Merumuskan indikator perilaku peserta didik di Madrasah

3) Mengembangkan silabus dan rencana pembelajaran berbasis pendidikan karakter

4) Mengintegrasikan konten kurikulum karakter ke mata pelajaran

5) Mengembangkan isntrumen penelitian (Ardi, 2012).

Selain perlu menyiapkan unsur pembentuk pembelajaran yang berkarakter, dalam pelaksanaan pembelajarannya tentunya terdapat beberapa faktor yang mempengaruhi proses pembelajaran, diantaranya adalah faktor guru dan faktor lingkungan belajar (Sanjaya, 2011). Faktor guru, dalam pembelajaran guru harus memahami hakekat pembelajaran yang diajarkannya sebagai suatu pelajaran yang dapat mengembangkan kemampuan berfikir peserta didik dan memahami berbagai model dan metode pembelajaran yang dapat merangsang kemampuan peserta didik untuk belajar dengan perencanaan pengajaran yang matang oleh guru.

2. Mata Pelajaran Akidah Akhlak di Madrasah Ibtidaiyah

Akidah akhlak merupakan mata pelajaran yang terdiri dari aspek akidah dan aspek akhlak. Akidah merupakan akar atau pokok agama. Aspek akidah menekankan pada kemampuan memahami dan mempertahankan keyakinan/ keimanan yang benar serta menghayati nilai-nilai asma' al husna. Aspek akhlak bertitik tolak dari akidah, yakni sebagai manifestasi dan konsekuensi dari keimanan dan keyakinan hidup. Akhlak merupakan aspek sikap hidup atau kepribadian hidup manusia, yang mengatur hubungan manusia dengan Allah SWT dan hubungan manusia dengan manusia lainnya. Hal itu menjadi sikap hidup dan kepribadian hidup manusia dalam menjalankan sistem kehidupannya (politik, ekonomi, sosial, pendidikan, kekeluargaan, Kebudayaan/seni, ilmu pengetahuan dan teknologi olahraga/kesehatan, dan lain-lain) yang dilandasi oleh akidah yang kokoh. Akidah Akhlak menekankan pada kemampuan memahami keimanan dan keyakinan Islam sehingga memiliki keyakinan yang kokoh dan mampu mempertahankan keyakinan/keimanannya serta menghayati dan mengamalkan nilai-nilai al-asma' al-husna. Akhlak menekankan pada pembiasaan untuk menerapkan dan menghiasi diri akhlak terpuji (mahmudah) dan menjauhi serta menghindari diri dari akhlak tercela (madzmumah) dalam kehidupan sehari-hari. 
3. Tujuan Mata Pelajaran Akidah Akhlak di Madrasah Ibtidaiyah

Mata Pelajaran Akidah-Akhlak di Madrasah Ibtidaiyah bertujuan untuk membekali peserta didik agar dapat:

1) Menumbuhkembangkan akidah melalui pemberian, pemupukan, dan pengembangan pengetahuan, penghayatan, pengamalan, pembiasaan, serta pengalaman peserta didik tentang akidah Islam sehingga menjadi manusia muslim yang terus berkembang keimanan dan ketakwaannya kepada Allah SWT;

2) Mewujudkan manusia Indonesia yang berakhlak mulia dan menghindari akhlak tercela dalam kehidupan sehari-hari baik dalam kehidupan individu maupun sosial, sebagai manifestasi dari ajaran dan nilai-nilai akidah Islam (Menteri Agama, 2013).

\section{Metode Pembelajaran Akidah Akhlak dalam Membentuk Karakter Peserta Didik.}

Adapun dalam pembelajaran akhlak Islam merupakan sistem moral/ akhlak yag berdasarkan Islam, yakni bersumber dari al Quran dan al Hadis. Dalam proses pembelajaran akidah akhlak, terdapat beberapa metode, diantaranya:

1. Metode Pembiasaan

Pembiasaan merupakan proses membuat sesuatu atau seseorang menjadi terbiasa. Dalam kaitannya dengan metode pembelajaran Islam. Dapat dikatakan bahwa pembiasaan adalah sebuah cara yang dilakukan untuk membiasakan anak didik berfikir, bersikap dan bertindak sesuai dengan tuntutan ajaran agama Islam (Maunah, 2009). Pembiasaan merupakan proses pembelajaran, yang dilakukan oleh orang tua atau pendidik kepada anak. Hal tersebut dimaksudkan agar anak mampu untuk membiasakan diri pada perbuatan-perbuatan yang baik dan dianjurkan baik oleh norma, agama maupun hukum yang berlaku.

2. Metode Keteladanan

Keteladanan adalah hal- hal yang ditiru atau dicontoh oleh seseorang dari orang lain. Keteladanan merupakan perilaku yang memberikan contoh kepada orang lain dalam hal kebaikan.

3. Metode pembelajaran Ganjaran dan Hukuman

Dalam bahsaa arab "ganjaran" diistilahkan dengan "tsawab". Kata "tsawab" bisa juga berarti pahala, upah dan balasan.Berkaitan dengan pendidikan Islam pemberian ganjaran yang baik terhadap perilaku baik dari anak didik.Hukuman dalam pendidikan berfungsi sebagai alat agar anak didik yang membuat kesalahan menjadi jera dan berupaya untuk tidak mengulanginya lagi, penerapan hukuman harus dapat meluruskan pelanggaran atau kesalahan yang dilakukan oleh anak didik menuju ke arah perbaikan (Iqbal, 2013).

4. Metode Kisah

Metode kisah ialah metode pendidikan dan pengajaran Islam melalui kisahkisah peristiwa yang telah terjadi pada masa lalu.Metode kisah sangat erat kaitannya 
dengan metode al-ibrah, yaitu merenungkan dan memikirkan kejadian-kejadian yang ada.

5. Metode Nasihat

Metode selanjutnya dalam pembelajaran akhlak adalah nasihat.Dinamakan nasihat karena dalam jiwa terdapat pembawaan untuk terpengaruh oleh kata- kata yang didengar.

6. Motivasi atau dorongan

Motivasi didefinisikan sebagai proses yang menstimulasi perilaku atau menggerakkan seseorang untuk bertindak. Motivasi adalah kekuatan yang menjadi pendorong kegiatan individu untuk melakukan kegiatan mencapai tujuan.

7. Metode Tazkiyat al Nafs

Tazkiyat berhubungan dengan pensucian hati, dalam hal ini bagaimana membentuk jiwa yang sadar akan dirinya, dengan artian bagaimana membentuk jiwajiwa yang tenang dan jiwa yang suci dalam menyikapi permasalahan.

8. Metode Ceramah

Metode ceramah ialah menyampaikan sebuah materi pelajaran dengan cara penuturan lisan pada peserta didik atau khalayak ramai. Ceramah juga diartkan sebagai penerangan dan penuturan lisan guru terhadap peserta didik di ruangan kelas (Ramayulis, 1990). Metode ini, menjadi salah satu metode Nabi dalam memberikan pelajaran terhadap umatnya.

\section{Model Pembelajaran Akidah Akhlak dalam Membentuk Karakter Peserta Didik}

Terdapat beberapa model pembelajaran, yang dapat diimplementasikan pada pembelajaran Akidah Akhak. Dalam hal ini, secara umum model pembelajaran PAI yang berorientasi pada pengembangan karakter pada bertujuan untuk merealisasikan nilai-nilai karakter dalam diri peserta didik. Kegiatan pembelajaran yang efektif dan efisien hendaknya diupayakan dalam merealisasikan nilai-nilai karakter. Beberapa model pembelajaran tersebut, diantaranya :

1. Pembelajaran Kontekstual (Contextual Teaching and Learning)

Pembelajaran kontekstual adalah proses pembelajaran holistik yang bertujuan untuk membelajarkan peserta didik dalam memahami bahan ajar secara bermakna yang dikaitkan dengan konteks kehidupan nyata, baik berkaitan dengan lingkungan, agama, sosial, ekonomi maupun kultural. Sehingga peserta didik memperoleh ilmu pengetahuan dan ketrampilan yang dapat diaplikasikan dan ditansfer dari suatu konteks permasalahan yang satu ke lainnya (Nanang Hanafiah, n.d.).

2. Pembelajaran Kooperatif (Cooperative Learning)

Pembelajaran kooperatif adalah upaya yang dilakukan oleh seorang pendidik untuk membelajarkan peserta didik kerjasama/gotong royong antar berbagai 
komponen, baik kerjasama antar peserta didik, pihak madrasah, anggota keluarga dan lainnya) (Yasin, 2007). Sebagai contoh, untuk mempelajari sejarah Nabi Muhammad SAW, peserta didik melakukan diskusi kelompok dengan tema-tema diskusi yang sudah ditentukan, sehingga dalam waktu yang singkat bisa diperoleh informasi yang lebih komprehensif tentang sejarah Nabi Muhammad saw. Melalui model ini guru bisa mengamati bagaimana peserta didik berdiskusi sambil memberikan penilaian proses terutama dalam penerapan nilai-nilai karakter, misalnya kecerdasan, keingintahuan, kesantunan, kedemokratisan, dan lain sebagainya. Peserta didik juga diminta untuk meneladani karakter-karakter mulia yang ada pada diri Nabi Muhammad SAW, seperti kejujuran, kecerdasan, kesabaran, kesantunan, kepedulian, dan ketangguhan (Hidayat, 2012).

3. Pembelajaran Berbasis Masalah

Belajar berdasarkan masalah adalah interaksi antara stimulus dan respon, merupakan hubungan antara dua arah belajar dan lingkungan. Lingkungan memberi masukan kepada peserta didik berupa bantuan dan masalah, sedangkan sistem saraf otak berfungsi menafsirkan bantuan itu secara efeketif sehingga masalah yang dihadapi dapat diselidiki, dinilai, dianalisis serta dicari pemecahnya dengan baik (Trianto, 2009).

4. Pembelajaran Model PAKEM (Pembelajaran Aktif, Kreatif, Efektif, dan Menyenangkan)

PAKEM merupakan model pembelajaran dan menjadi pedoman bertindak untuk mencapai tujuan yang telah ditetapkan. Dengan pelaksanaan pembelajaan PAKEM, diharapkan berkembangnya berbagai macam inovasi kegiatan pembelajaran untuk mencapai tujuan pembelajaran yang partisipasif, aktif, kreatif dan menyenangkan.

5. Pemodelan

Dalam pembelajaran mata pelajaran akidah akhlak terutama untuk pembinaan karakter para siswa, pemodelan (pemberian uswah hasanah/teladan yang baik) merupakan metode yang cukuf efektif.

\section{Budaya Religius di Madrasah Ibtidaiyah}

1. Budaya Religius di Madrasah Ibtidaiyah

Budaya religius Madrasah merupakan cara berfikir dan cara bertindak warga madrasah yang didasarkan atas nilai- nilai religius (keberagmaan). Budaya agama yang dimaksudkan dalam hal ini memiliki makna yang sama dengan "suasana religius" Adapun makna suasa religius menurut Muhamimin adalah suasana atau iklim kehidupan keagamaan yang dampaknya ialah berkembangnya suatu pandangan hidup yang bernapaskan atau dijiwai oleh ajaran agama yang diwujdukan dalam 
sikap hidup serta ketrampilan hidup oleh warga sekolah/madrasah (Muhaimin, 2012). Jadi maksud "budaya religius" adalah nilai-nilai ajaran agama yang mendasari perbuatan, perkataan dan keseharian warga sekolah/madrsah yang dilakukan secara konsisten di lingkungan sekolah/madrasah. Budaya agama terbentuk dari nilai- nilai ajaran agama sebagai tradisi dalam berperilaku dan budaya organisasi yang diikuti oleh seluruh warga sekolah. Dalam tataran nilai, budaya religius berupa semangat berkorban, semangat persaudaraan, semnagat saling menolong dan tradisi mulia lainnya.Sedangkan dalam tataran perilaku, budaya religius berupa tradisi sholat berjamaah, gemar bershodaqoh, rajin belajar dan perilaku yang mulia lainnya.

2. Pentingnya Penciptaan Budaya Religius di Madrasah Ibtidaiyah

Konsep religius pendidikan dapat diartikan bahwa religius pendidikan menumbukan kecerdasan spiritual kepada siswa dalam pendidikan dan kehidupan. Religius pendidikan melalui kecerdasan spiritual juga memberi guide line kepada guru untuk mengerjakan arti pentingnya religius kepada para peserta didiknya. Religiuitas pendidikan menajamkan kualitas kecerdasan spiritual terhadap guru maupun siswa, hal tersebut dilakukan dengan menginternalisasikan nilai-nilai kejujuran, keadilan, kebijakan, kebersamaan, kesetiakawanan sosial kepada siswa sejak usia dini,dan untuk guru juga dapat memperoleh hal tersebut melalui sikap keteladanan dalam setiap proses yang terjadi dalam pendidikan (Sahlan, n.d.). Dalam hali ini, nilai- nilai religius dapat diperoleh dengan jalan merealisasikan tiga nilai kehidupan yang saling terkait satu sama lainnya, yaitu: Creative values ( nilai- nilai kreatif), dalam hal ini berbuat kebajikan dan melakukan hal- hal yang bermanfaat bagi lingkungan termasuk usaha merealisasikan nilai-nilai kreatif, Experimental values ( nilai- nilai penghayatan); meyakini dan menghayati kebenaran, kebajikan, keindahan, keimanan dan nilai- nilai yang dianggap berharga Attitudes values (nilainilai bersikap); menerima dengan tabah dan mengambil sikap yang tepat terhadap penderitaan yang tak dapat dihindari lagi setelah melakukan upaya secara optimal, tetapi tidak berhasil mengatasinya (Sahlan, n.d.).

Ashgar mengungkapkan bahwa orang mukmin sejati adalah orang yang penuh kesabaran, tanpa kekerasan, adil, menghargai kesetaraan, mencintai sesama dan ia adalah orang yang sarat kasih sayang dan toleransi (Engineer, 2004). Adapun sikap religius, menurut gay hendricks dan Kate Ludeman dalam Asmaun sahlan, terdapat beberapa sikap religius yang tampak dalam diri seseorang dalam menjalankan tugasnya antara lain:

1) Kejujuran

2) Keadilan

3) Bermanfaat bagi Orang lain

4) Rendah hati 
5) Bekerja Efisien

6) Visi ke depan

7) Disiplin tinggi

8) Keseimbangan.

Dapat dipahami, bahwa nilai religius dalah nilai-nilai kehidupanyangmencerminkan tumbuh kembangnya kehidupan beragama yang terdiri dari tiga unsur pokok yaitu aqiqah, ibadah dan akhlak yang menjadi pedoman perilaku sesuai dengan aturan- aturan ilahi untuk mencapai kesejahteraan serta kehidupan hidup di dunia dan akhirat. Budaya religius madrasah pada hakikatnya adalah terwujudnya nilai-nilai ajaran agama sebagai tradisi dalam berperilaku dan budaya organisasi yang diikuti oleh seluruh warga madrasah (Asmaun, n.d.). Dari pemaparan konsep di atas, jelas bahwa uregensi budaya religius di madrasah untuk membentuk sikap religius bagi semua warga madrasah, khususnya untuk membina agama peserta didik, baik dari segi kognitif, afektif dan psikomotorik.

3. Strategi Membudayakan Nilai- Nilai Agama di Madrasah Ibtidaiyah

Terdapat beberapa strategi yang dapat dilakukan untuk membentuk budaya religius di Madrasah, diantaranya melalui;

1. Pemberian contoh teladan

2. Membiasakan hal- hal yang baik

3. Menegakkan disiplin

4. Memberikan motivasi dan dorongan

5. Memberikan hadiah terutama psikologis

6. Pemberian hukuman untuk kedisiplinan

7. Penciptaan suasana religius yang berpengaruh bagi pertumbuhan anak (Tafsir, 2004).

Adapun menurut Muhaimin strategi nilai- nilai agama di madrasah dapat dilakukan melalui:

1. Power strategy, yakni strategi membudayakan agama di madrasah dengan cara menggunakan kekuasaan, dalam hal ini peran kepala sekolah dengan segala kekuasaannya sangat dominan dalam melakukan perubahan.

2. Persuasive strategy, yang dijalankan lewat pembentukan opini dan pendangan masyarakat atau warga madrasah.

3. Normative re ducative, dikembangkan melalui pembiasaan, keteladanan dan pendekatan persuasif atau mengajak kepada warganya dengan cara yang halus, dengan memberikan alasan dan prospek baik yang bisa meyakinkan (Muhaimin, 2005). 


\section{Pembentukan Karakter di Madrasah Ibtidaiyah}

\section{Pengertian Pendidikan Karakter}

Karakter merupakan suatu keadaan jiwa. Keadaan ini menyebabkan jiwa bertindak tanpa pikir atau dipertimbangkan secara mendalam. Keadaan ini ada dua jenis. Yang pertama, alamiah dan bertolak dari watak. Misalnya pada orang yang gampang sekali marah karena hal-hal yang paling kecil. Yang kedua, tercipta melalui kebiasaan dan latihan. Pada mulanya keadaan ini terjadi karena dipertimbangkan dan difikirkan. Namun, kemudian melalui pratek terus menerus menjadi karakter (Abu Ali Akhmad Al-Miskawaih, Tahdhib Al-Akhlak, 1994).

Karakter dalam perspektif Islam, dalam hal ini, pendidikan karakter memberikan pesan bahwa spiritualitas dan nilai- nilai agama tidak bisa dipisahkan dari pendidikan karakter. Moral dan nilai- nilai spiritual sangat fundamental dalam membangun kesejahteraan dalam organisasi sosial manapun. Tanpa keduanya maka elemen vital yang mengikat kehidupan masyarakat dapat lenyap. Dalam Islam tidak ada disiplin ilmu yang terpisah dari etika- etika Islam. Dalam Islam terdapat tiga nilai utama yaitu akhlak, adab dan keteladanan. Nilai- nilai Pendidikan Karakter dalam Madrasah Ibtidaiyah Menurut kementrian Pendidikan Nasional, nilai karakter bangsa terdiri atas: Religius, Jujur, Toleransi, Disiplin, Kerja keras, Kreatif, Mandiri, Demokratis, Rasa ingin tahu, Semangat kebangsaan, Cinta tanah Air, Menghargai prestasi, Bersahabat komunikatif, Cinta damai, Gemar membaca, Peduli lingkungan, Peduli sosial dan Tanggung Jawab.

2. Pembentukan Karakter Melalui Pembudayaan

Untuk membangun budaya dalam rangka membentuk karakter pada peserta didik, langkah yang perlu dilakukan adalah menciptakan susasa yang berkarakter (penuh dengan nilai- nilai) terlebih dahulu. Penciptaan suasana berkarakter sangat dipengaruhi oleh situasi dan kondisi tempat model itu akan diterapkan beserta penerapan nilai-nilai yang mendasarinya. Pertama, penciptaan budaya berkarakter yang bersifat vertikal (ilahiah). Kegiatan ini dapat diwujudkan daam bentuk hubungan dengan Allah SWT, melalui peningkatan secara kuantitas maupun kualitas kegiatan- kegiatan keagamaan di sekolah yang bersifat ubudiyah seperti shalat berjamaah, puasa senin dan kamis, membaca Al Quran, doa bersama dan lain sebagainya. Kedua penciptaan berkarakter yang bersifat horizontal (insaniah), yaitu lebih mendudukkan sekolah sebagai institusi sosial, yang apabila dilihat dari struktur hubungan antar manusianya dapat diklasifikasikan ke dalam tiga hubungan yaitu (1) hubungan atas- bawahan, (2) hubungan profesional, (3) hubungan sederajat atau sukarela yang didasarkan pada nilai-nilai positif, seperti persaudaraan, kedermawanan, kejujuran, saling menghormati, dan sebagainya. 


\section{B. Metode}

1. Pendekatan dan Jenis Penelitian

Penelitian yang berfokus pada Pembelajaran Akidah Akhlak dalam Membentuk Karakter Peserta Didik Melalui Budaya Religius didesain dengan menggunakan pendekatan kualitatif, jenis penelitian studi kasus dengan spesifikasi studi multi kasus. Artinya penelitian akan menggunakan lebih dari satu kasus untuk diteliti yaitu di MIN Plosorejo Blora dan MI Tarbiyatul Islamiyah Winong Pati. Dalam penelitian multikasus ini, berupaya mengkaji subjek tertentu dan memperbandingkan atau mempertentangkan beberapa subjek tertentu.

2. Kehadiran Peneliti

Dalampenelitian ini, peneliti bertindak sebagai key instrument penelitian, sehingga peran peneliti sebagai instrumen peneliti menjadi suatu keharusan bahkan kehadiran peneliti dalam penelitian kualitatif mutlak diperlukan. Karena validitas dan reliabilitas data kualitatif banyak bergantung pada ketrampilan metodologis, kepekaan dan integrasi peneliti sendiri.Sebagai instrumen kunci, peneliti merupakan perencana, pengumpul dan menganalis data sekaligus menjadi pelopor dari hasil penelitiannya sendiri. Karena peneliti harus bisa menyesuaikan diri dengan situasi dan kondisi lapangan.

3. Data, Sumber Data dan Isntrumen Penelitian

a. Data

1) Data Primer

Dalam penelitian ini, data primer yang akan digunakan oleh peneliti yaitu berupa data verbal dari hasil wawancara dengan para informan yang kemudian peneliti catat dalam bentuk catatan tertulis, rekaman dengan menggunakan recorder, serta pengambilan foto. Sedangkan data dari pengamatan langsung akan peneliti catat dalam bentuk catatan lapagan.

2) Data Sekunder

Sumber data sekunder adalah data yang diperoleh dari studi dokumentasi yang diperoleh dari MIN Plosorejo Blora dan MI Tarbiyatul Islamiyah Winong Pati, literatur-literatur dan sumber bacaan lain yang berkaitan dengan tema penelitian. Sumber data ini merupakan sumber data yang sifatnya mendukung, dapat berupa dokumen, laporan, arsip- arsip serta suasana dan kontak sosial yang terjadi di lokasi penelitian.

b. Sumber Data

Sumber data dalam penelitian ini dapat dibedakan menjadi dua, yaitu manusia (human) dan non manusia. Sumber data manusia berfungsi sebagai subjek atau informasi dan data yang diperoleh melalui informan bersifat data lunak. Sedangkan sumber data bukan manusia berupa dokumen yang relevan 
dengan fokus penelitian, seperti foto, gambar, catatan atau tulisan yang ada kaitannya dengan fokus penelitian. Adapun dalam pengambilan informan dilakukan dengan cara sampling purposive dan snowbal. Teknik sampling purposive dilakukan untuk subjek dan informan yang dipilih adalah orang yang mampu memberikan informasi seluas mungkin mengenai fokus penelitian. Dengan demikian tidak semua objek dan informan atau unsur dengan latar belakang yang diselidiki mempunyai peluang yang sama untuk terpilih sebagai sampel. Sedangkan snowball sampling, teknik ini dilakukan untuk menggali informasi secara terus menerus dari informan satu ke informan lainnnya, sehingga data yang diperoleh dianggap telah jenuh.

c. Teknik Pengumpulan Data

1) Metode wawancara terstruktur dan indepth interview

Wawancara yang akan peneliti lakukan yaitu Indepth interview ialah wawancara yang dilakukan pada saat mengamati langsung obyek penelitian, di mana peneliti ikut berperan aktif dalam kegiatan yang dilakukan oleh obyek yang diamati, tanpa harus menafsirkan sesuatu yang sedang dipelajari.

2) Metode Observasi

Adapun hal-hal yang akan peneliti observasi secara partisipasif ketika di lapangan yaitu:

a) Pelaksanaan pembelajaran akidah akhlak dalam kegiatan pembelajaran, maupun dalam kegiatan pengembangan diri yang berkaitan dengan mata pelajaran akidah akhlak seperti ekstrakulikuler, kegiatan pembiasaan dan kegiatan Madrasah lainnya.

b) Kegiatan keagamaan yang merupakan budaya religius di MIN Plosorejo dan MI Tarbiyatul Islamiyah Winong Pati

c) Situasi dan kondisi Madrasah, sarana dan prasarana Madrasah, data-data dokumentasi Madrasah dan lain sebagainya yang relevan dengan fokus penelitian.

d) Perilaku peserta didik di kelas maupun di luar kelas di MIN Plosorejo dan Tarbiyatul Islamiyah Winong Pati

e) Perilaku peserta didik terhadap guru, maupun sesama teman di MIN Plosorejo dan Tarbiyatul Islamiyah Winong Pati

f) Interaksi peserta didik dengan teman, guru dan lingkungan di MIN Plosorejo dan MI Tarbiyatul Islamiyah Winong.

i) Metode Dokumentasi, Metode dokumentasi yaitu mencari data mengenai hal-hal atau variabel berupa catatan, transkip, buku, surat kabar, majalah, prasasti, notulen rapat, legger, dan sebagainya (Arikunto, 1992). Adapun dokumen yang akan peneliti gunakan untuk menganalisis model 
pembelajaran akidah akhlak dalam membentuk karakter peserta didik melalui budaya religius.

d. Teknik Analisa Data

Analisis data adalah proses mengorganisasikan dan mengurutkan data ke dalam pola, kategori dan satuan uraian dasar sehingga dapat ditemukan tema dan dapat dirumuskan hipotesis kerja seperti yang disarankan oleh data (Moleong, 2005). Dalam teknis analisis data, peneliti menggunakan analisis data menurut Miles dan Huberman. Menurut Miles dan Huberman yang dikutip oleh Sugiyono, disebutkan bahwa analisis data ini meliputi kegiatan pengumpulan data, reduksi data dan verifikasi data (Sugiyono, 2007). Sebagai berikut:

a. Pengumpulan data

b. Reduksi data

c. Penyajian data

d. Verifikasi Data

Dalam penelitian ini, dalam memverifikasi data, Menurut Robert K.Yin dalam penelitian multikasus, ada dua langkah yang harus dilakukan dalam analisis data kasus individu (individual cases analysisis), dan analisis lintas kasus (cross cases analysis) (Yin, 2006),

a. Analisis data kasus individu

b. Analisis data lintas kasus

e. Pengecekan Keabsahan Data

1) Kredibiliti

Peneliti sebagai instrumen utama dalam penelitian ini banyak berperan dalam menentukan dan menjustifiikasi data, sumber data kesimpulan dan hal- hal penting lain. Untuk memeriksa keabsahan data yaitu dengan menggunakan triangulasi data. Triangulasi yaitu teknik pemeriksaan keabsahan data yang memanfaatkan sesuatu yang lain di luar data itu untuk keperluan pengecekan atau sebagai pembanding data tersebut (Moleong, 2005). Dengan teknik, penelitian yang diharapkan dapat melakukan check and recheck hasil temuan dengan jalan membanding-bandingkan dengan berbagai sumber, metode dan teori. Adapun untuk penelitian ini, peneliti akan menggunakan teknik triangulasi data (Ghony, 2012).

2) Dependibilitas

Kriteria ini untuk menilai apakah teknik penelitian bermutu dari segi prosesnya. Kriteria ini digunakan untuk menjaga kehati-hatian akan terjadinya kemungkinan kesalahan dalam konseptualisai rencana penelitian, pengumpulan data, interpretasi temuan dan laporan hasil penelitian sehingga semuanya dapat dipertanggung jawabkan secara ilmiah. 
3) Konfirmabilitas

Konfirmabilitas atau kepastian diperlukan untuk mengetahui apakah data yang diperoleh objektif atau tidak. Dalam hai ini untuk mengecek derajat kepastian pada penelitian ini adalah auditing (review) dari sejawat atau pembimbing. Hal-hal yang dimintakan untuk review diantaranya adalah apakah temuan hasil penelitian benar-benar berasal dari lapangan berdasarkan data mentah: wawancara, obeservasi dan dokumentasi; apakah kesimpulan yang diambil peneliti itu logis berdasarkan data, fenomena dan fakta dengan melihat teknik analisis yang digunakan, kecukupan label kategori, kualitas penafsiran dan kemungkinan adanya pembanding; juga yang tidak kalah pentingnya adalah menyangkut ketelitian peneliti,apakah ada kemencengan atau pembelokan dari fokus yang dikaji, dan menelaah kegiatan peneliti dalam melaksanakan pemeriksaan keabsahan data. 


\section{Hasil dan Pembahasan}

\section{Pelaksanaan Pembelajaran Akidah Akhlak Melalui Religious Culture}

Pelaksanaan pembelajaran akidah akhlak dalam membentuk karakter peserta didik melalui budaya religius di MIN Plosorejo dilaksanakan dengan jelas, terarah dan sistematis sebagaimana gambar Bagan Model Pembelajaran Akidah Akhlak dalam membentuk Karakter Peserta didik di MIN Plosorejo Blora

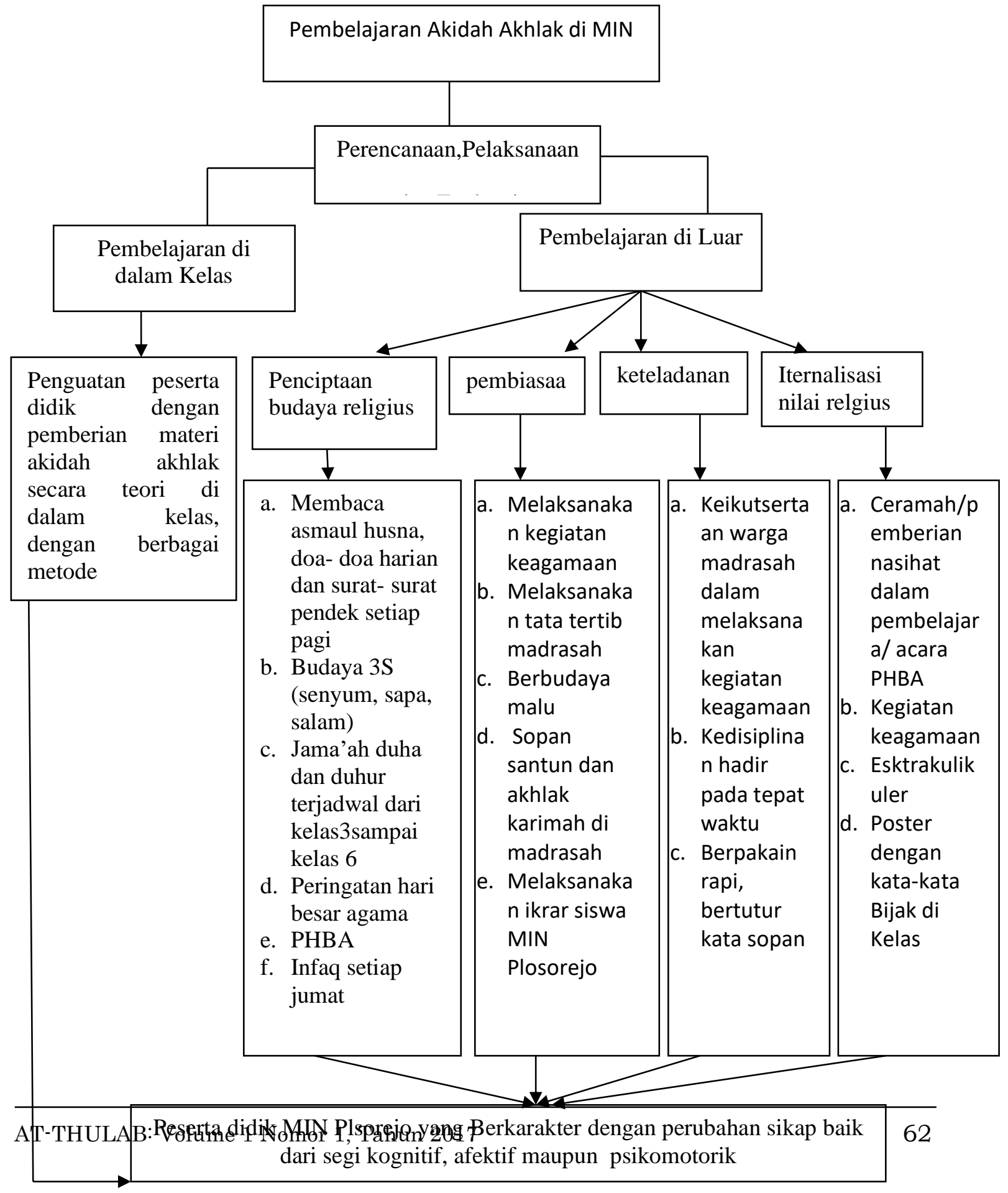


Dapat diambil sebuah kesimpulan bahwa pelaksanaan pembelajaran akidah akhlak melalui budaya religius di MIN Plosorejo dengan menggunakan model pembelajaran CTL Contekstual Teaching and Learning. Dari beberapa temuan tersebut, ditemukan bahwa pelaksanaan pembelajaran akidah akhlak dalam membentuk karakter peserta didik melalui budaya religius di MI Tarbiyatul Islamiyah dilaksanakan dengan jelas, terarah dan sistematis. Dalam upaya membentuk karakter peserta didik, materi akidah akhlak disampaikan tidak sekedar dalam bentuk teori tetapi juga didukung dengan amaliah keseharian dari materi akidah akhlak secara aktif melalui budaya religius yang diwujudkan dalam bentuk kegiatan keagamaan dengan didukung metode- metode pembelajaran untuk mencapai tujuan pembelajaran yang dicita- citakan. Hasil temuan antara MIN Plosorejo dan MI tarbiyatul Islamiyah hampir sama terkait dengan fokus penelitin, akan tetapi terdapat perbedaan diantara kasus 1 dan kasus 2, dimana pada penciptaan budaya religius yang ada di MI Tarbiyatul Islamiyah, bahwa budaya yang diciptakan didasari dengan prinsip- prinsip nahdiyiin, sehingga pola pelaksanaan budaya kental dengan budaya nahdiyiin, selain itu MI Tarbiyatul Islamiyah merupakan MI yang berbasis tahfid dengan didukung pesantren tahfid sehingga dampak pelaksanaan pembelajaran akidah yang terbentuk di MI Tarbiyatul Islamiyah adalah karakter peserta didik yang berlandaskan pada akhlak karimah dengan mencetak peserta didik yang mencintai al quran dengan menghafal al quran dan mengaplikasikan akhlak al quran dalam bentuk amaliah keseharian melaui kegiatan keagamaan yang dibiasakan setiap hari di madrasah. Dapat diambil sebuah kesimpulan bahwa pelaksanaan pembelajaran akidah akhlak melalui budaya religius di MI Tarbiyatul Islamiyah dengan menggunakan model pembelajaran CTL Contekstual Teaching and Learning, hal ini dilihat dari proses pembelajaran akidah akhlak yang dilaksanakan di MI Tarbiyatul Islamiyah tidak sekedar menanamkan materi yang sifatnya abstrak tetapi lebih pada praktik pembelajarannya, yang terwujud melalui budaya religius dengan berbagai stratregi dan metode pembelajaran yang mendukung. Untuk lebih mudahnya berikut model pembelajaran akidah akhlak dalam membentuk karakter peserta didik di MIN Plosorejo Blora: 


\section{BaganTemuan Model Pembelajaran akidah akhlak dalam membentuk Karakter Peserta} didik di MI Tarbiyatul Islami

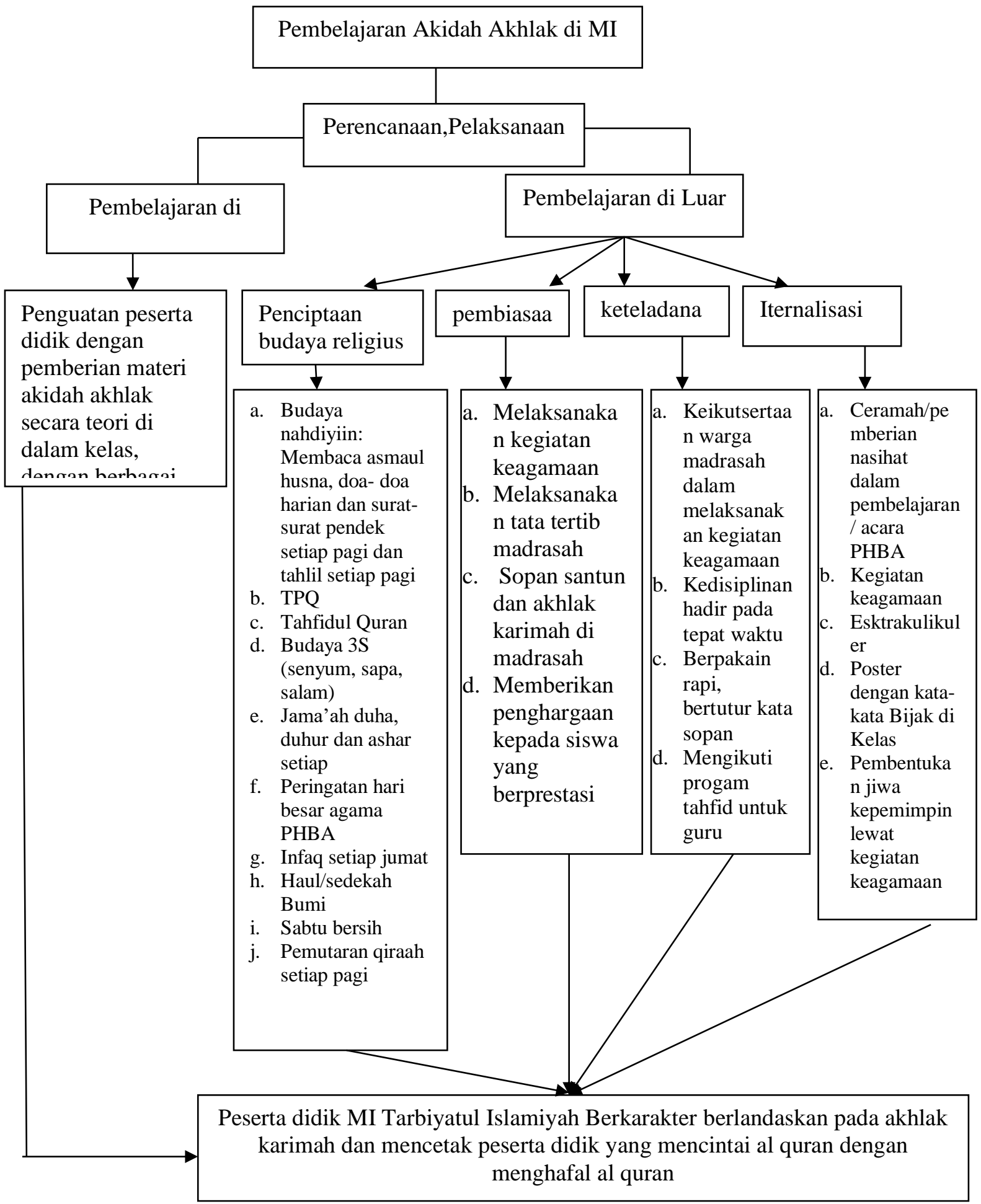




\section{Dampak Pembelajaran Akidah Akhlak melalui budaya religius dalam membentuk karakter peserta didik}

Dalam sebuah pembelajaran, tentunya ada tujuan pembelajaran yang ingin dicapai. Pada dasarnya hasil dari sebuah pembelajaran adalah perubahan perilaku peserta didik. Untuk melihat hasil dari sebuah pembelajaran, adalah ditandainya perubahan pada diri seseorang sebagai hasil pengalaman dan latihan. Perubahan sebagai hasil dari belajar dapat ditimbulkan dalam berbagai bentuk, seperti berubahnya tingkah laku kecakapan serta kemampuan. Menurut Ahmad Mudzakar bahwa belajar adalah usaha atau kegiatan yang bertujuan mengadakan perubahan dalam diri seseorang mencakup perubahan tingkah laku, sikap kebiasaan,ilmu pengetahuan, ketrampilan dan sebagainya (Anas, n.d.).

Perubahan yang terjadi sebagai hasil belajar beranjak dari taksonomi Bloom meliputi domain berikut:

1. Ranah Kognitif berisi perilaku yang menekankan aspek intelektual, seperti pengetahuan, dan keterampilan berpikir. Kognitif menekankan pada Knowledge. Dalam aspek ini berupa perubahan dari segi penguasaan pengetahuan dan perkembangan ketrampilan yang diperlukan untuk memanfaatkan pengetahuan tersebut dalam kehidupan

2. Ranah afektif/Attitude mencakup perilaku terkait dengan emosi, misalnya perasaan, nilai, minat, motivasi, dan sikap. Perubahan yang diharapkan adalah perubahan dari sikap mental, perasaan dan kesadaran.

3. Sedangkan ranah Psikomotorik/ Skill berisi perilaku yang menekankan fungsi manipulatif dan keterampilan motorik / kemampuan fisik. Aspek Psikomotorik meliputi perubahan dari segi bentuk bentuk tindakan motorik.

Berdasarkan Konsep tersebut, maka dampak pembelajaran yang peneliti analisis adalah bagaimana pembelajaran akidah akhlak melalui budaya religius yang diajarkan bisa membentuk karakter peserta didik, dengan ditandainya perubahan pada ketiga aspek yang meliputi kognitif, afektif dan psikomotorik peserta didik. Adapun karakter peserta didik, menurut Kementrian Pendidikan Nasional terdiri atas (Zubaedi, 2012)

Temuan penelitian di MIN Plosorejo dan MI Tarbiyatul Islamiyah pembelajaran akidah akhlak melalui budaya religius mampu membentuk karakter peserta didik dengan ditandainya perubahan pada ketiga aspek (kognitif, afektif dan psikomotorik), hal tersebut terbentuk karena adanya pembinaan terpadu antara ketiga dimensi, 1) pengetahuan yang baik (moral knowing), yang meliupti Pengetahuan tentang nilai-nilai moral (Knowing moral values), Penentuan sudut pandang (Prespective-taking), Logika moral (moral reasoning), Keberanian mengambil sikap (decision making) dan Pengenalan diri (self-knowledge). 2) Perasaan yang baik atau 
loving good (moral feeling) yang meliputi Memiliki jati diri /nurani (conscience), Percaya diri (self-esteem), Kepekaan terhadap derita orang lain (empathy), Cinta kebenaran(loving the good), Pengendalian diri(self-control)Kerendahan hati (humality) dan 3) perilaku yang baik (moral action) sehingga terbentuk Kompetensi (competence), memilikiKemauan (will), Terbiasa (habit). perwujudan kesatuan perilaku dan sikap

\section{Simpulan}

Berdasarkan paparan data dan temuan penelitian di lapangan serta hasil analisis pembahasan, sebagai berikut:

1. Model pembelajaran akidah akhlak melalui budaya religius di MIN Plosorejo Blora dan MI Tarbiyatul Islamiyah Winong Pati adalah Pembelajaran yang dilaksanakan secara kontekstual dalam bentuk pembelajaran PAKEM di dalam kelas dan pembelajaran di luar kelas melalui penanaman nilai religius dan berbagai metode pembelajaran, yaitu penciptaan budaya religius, ceramah dan pemberiaan nasihat, keteladan, pembiasaan, kegiatan ekstrakulikuler, poster berisi hadis atau kata motivasi yang ditempel di dinding madrasah, pembentukan jiwa kepemimpinan melalui kegiatan keagamaan. Pembelajaran akidah akhlak yang diwujudkan melalui budaya religius di MIN Plosorejo dan MI Tarbiyatul Islamiyah diantaranya; membaca tahlil setiap pagi, membaca asmaul husna setiap pagi, Jamaah sholat duha, Jamaah duhur dan ashar, Tahfidzul quran, TPQ, Sedekah Bumi, Pemutaran qiraah di pagi hari, Infaq di hari jumat, Sabtu bersih, dan Peringatan Hari Besar Islam (PHBI).

2. Dampak pembelajaran akidah akhlak melalui budaya religius di MIN Plosorejo Blora dan MI Tarbiyatul Islamiyah Winong Pati mampu membentuk karakter peserta didik, dengan ditandainya perubahan perilaku peserta didik yang meliputi tiga aspek kognitif, afektif dan psikomotorik peserta didik. Materi akidah dan akhlak yang diwujudkan melalui budaya religius membentuk karakter peserta didik yang berlandaskan pada akhlak karimah, religius, bertanggung jawab, sopan santun, peduli lingkungan, bertanggung jawab, peduli sosial, dan rasa ingin tahu dan membentuk peserta didik yang berprestasi dalam berbagai bidang akademik.

Sebagai kesimpulan dari pelaksanaan pembelajaran akidah akhalak dalam membentuk karakter peserta didik di MIN Plosorejo dan MI Tarbiyatul Islamiyah, adalah terbentuknya sebuah model pembelajaran kontekstual. Hal ini berdasarkan konsep bahwa pembelajaran kontekstual adalah proses pembelajaran holistik yang bertujuan untuk membelajarkan peserta didik dalam memahami bahan ajar secara bermakna yang dikaitkan dengan konteks kehidupan nyata, baik berkaitan dengan lingkungan, agama, sosial, ekonomi maupun kultural. Sehingga peserta didik memperoleh ilmu pengetahuan dan ketrampilan yang dapat diaplikasikan dan ditansfer 
dari suatu konteks permasalahan yang satu ke lainnya (Nanang Hanafiah, n.d.). Realitas yang ditemukan bahwa madrasah dengan berbagai upaya melaksanakan pembelajaran yang tidak hanya secara teortis tetapi lebih kepada pembelajaran yang bermakna yang dikaitkan dengan konteks kehidupan nyata. Melalui budaya reli\ ius peserta didik, merasakan pembelajaran yang kongkrit, apa yang diperoleh melalui secara teori diaplikasikan secara langsung melalui budaya religius dengan berbagai metode pembelajaran. Diantaranya adalah menerapkan materi akidah dan akhlak melalui budaya religius, diantaranya: jama'ah shalat duha dan dhuhur, pembacaan asmaul husna, doa sehari- hari, TPQ. Tahfidul Qura'an, pembiasaan 3S, PHBA dan penerapan akhlakul karimah.

\section{Daftar Rujukan}

Abu Ali Akhmad Al-Miskawaih, Tahdhib Al-Akhlak, T. H. H. (1994). Мепијu Kesempurnaan Akhlak. Bandung: Mizan.

Anas. (n.d.). Pendidikan berbasis karakter Pendidikan berbasis agama dan budaya bangsa.

Ardi, N. (2012). Membumikan Pendidikan Karakter di SD. Yogyakarta: Ar Ruz Media.

Arikunto, S. (1992). Produser Penelitian Suatu Pendekatan Praktek. Jakarta: Rienika Cipta.

Asmaun. (n.d.). Mewujudkan Budaya Religius.

Engineer, A. A. (2004). Liberalisasi Teologi Islam Membangun Teologi Damai dalam Islam. Yogyakarta: Alenia.

Ghony, M. D. (2012). Metode Penelitian Kualitatif. Yogyakarta: Ar- Ruzz Media.

Hidayat. (2012). Model Pembelajaran Pendidikan Agama Islam Berorientasi Pengembangan Karakter Bangsa. Jurnal El Hikmah, IX(2), 153.

Iqbal, A. M. (2013). Konsep Pemikiran Al Ghazali Tentang Pendidikan. Madiun: Jaya Star Nine.

Maunah, B. (2009). Metodologi Pengajaran Agama Islam. Yogyakarta: Teras.

Menteri Agama. Kurikulum Madrasah 2013 Mata Pelajaran Pendidikan Agama Islam Dan Bahasa Arab. , (2013).

Moleong, L. J. (2005). Metodologi Penelitian Kualitatif. Bandung: Remaja Rosdakarya.

Muhaimin. (2004). Wacana Pengembangan Pendidikan Islam. Surabaya: Pustaka Pelajar.

Muhaimin. (2005). Pengembangan Kurikulum Pendidikan Islam di Sekolah, Madrasah, dan Perguruan Tinggi. Jakarta: Raja Grafindo Persada.

Muhaimin. (2012). Pengembangan Kurikulum Pendidikan Agama Islam di Sekolah, Madrasah dan Perguruan Tinggi. Jakarta: Rajawali Pers.

Nanang Hanafiah, C. S. (n.d.). Konsep Strategi Pembelajaran. Bandung: Refika 
Model Pembelajaran Akidah Akhlak Melalui ...

Aditama.

Nasional, D. P. Undang-undang Republik Indonesia tentang Sistem Pendidikan Nasional. , (2003).

Permenag. Standar Kompetensi Lulusan Dan Standar Isi Pendidikan Agama Islam dan Bahasa Arab di Madrasah. , (2008).

Ramayulis. (1990). Metode Pengajaran Agama Islam. Jakarta: Kalam Mulia.

RI, K. (2011). Pendidikan Kewarganegaraan Budaya dan Agama. Jakarta: Kemenag RI.

Sahlan, A. (n.d.). Mewujudkan Budaya Religius di Sekolah Upaya mengembangkan PAI dari Teori ke Aksi.

Sanjaya, W. (2011). Strategi Pembelajaran Berorientasi Standar Proses Pembelajaran. Jakarta: Kencana Prenada Media.

Sugiyono. (2007). Metode Penelitian Pendidikan. Bandung: Alfabeta.

Tafsir, A. (2004). Metodologi Pengajaran Agama Islam. Bandung: Remaja Rosdakarya.

Trianto. (2009). Mendesain Model Pembelajaran Inovatif- Progesif. Jakarta: Prenada Media Group.

Yasin, F. (2007). Metodologi Pendidikan Islam. Malang: Pusapom.

Yin, R. K. (2006). Studi Kasus: Desain dan Metode, Terj. M. Djauzi Mudzakir. Jakarta: Raja Grafindo Persada.

Zubaedi. (2012). Desain Pendidikan Karakter Konsepsi dan Aplikasinya dalam Lembaga Pendidikan. Jakarta: Kencana Prenada Media Group. 